Fixed Point Theory, 21(2020), No. 1, 133-150

DOI: $10.24193 /$ fpt-ro.2020.1.10

http://www.math.ubbcluj.ro/ nodeacj/sfptcj.html

\title{
THE COMPLETION OF GENERALIZED B-METRIC SPACES AND FIXED POINTS
}

\author{
ŞTEFAN COBZAŞ* AND STEFAN CZERWIK** \\ *Babeş-Bolyai University, Department of Mathematics, Cluj-Napoca, Romania \\ E-mail:scobzas@math.ubbcluj.ro \\ **Silesian University of Technology, Institute of Mathematics, Gliwice, Poland \\ E-mail: steczerw@gmail.com
}

\begin{abstract}
We introduce the notion of generalized b-metric, as a b-metric which can take infinite values, and prove the existence and uniqueness of the completion of some particular b-metric spaces (called generalized strong b-metric spaces). Some fixed point results in b-metric spaces and their counterparts in generalized b-metric spaces are proved.

Key Words and Phrases: Metric space, metrizability, b-metric space, generalized b-metric space, completion of a generalized b-metric space, fixed point.

2010 Mathematics Subject Classification: 54E25, 54D35, 54E35, 54E50, 47H10.
\end{abstract}

Acknowledgements. The authors express their thanks to the reviewer, whose pertinent remarks and suggestions lead to a substantial improvement of the presentation.

\section{REFERENCES}

[1] H. Aimar, B. Iaffei, L. Nitti, On the Macias-Segovia metrization of quasi-metric spaces, Rev. Unión Mat. Argent., 41(1998), no. 2, 67-75.

[2] T.V. An, N.V. Dung, Remarks on Frink's metrization technique and applications, arXiv preprint, arXiv:1507.01724 (2015), 15 p.

[3] T.V. An, L.Q. Tuyen, N.V. Dung, Stone-type theorem on b-metric spaces and applications, Topology Appl., 185-186(2015), 50-64.

[4] T.V. An, L.Q. Tuyen, N.V. Dung, Answers to Kirk-Shahzad's questions on strong b-metric spaces, Taiwanese J. Math., 20(2016), no. 5, 1175-1184.

[5] H. Aydi, S. Czerwik, Fixed point theorems in generalized b-metric spaces, in: Modern Discrete Mathematics and Analysis. With Applications in Cryptography, Information Systems and Modeling, (N.J. Daras, Th.M. Rassias - Eds.) Cham: Springer, 2018, pp. 1-9.

[6] I.A. Bakhtin, The contraction mapping principle in quasimetric spaces, (Russian), Funktionalnyi Analyz, Ulianovskii Gos. Ped. Inst., 30(1989), 26-37.

[7] G. Beer, The structure of extended real-valued metric spaces, Set-Valued Var. Anal., 21(2013), no. $4,591-602$.

[8] G. Beer, Norms with infinite values, J. Convex Anal., 22(2015), no. 1, 37-60.

[9] G. Beer, J. Vanderwerff, Separation of convex sets in extended normed spaces, J. Aust. Math. Soc., 99(2015), no. 2, 145-165.

[10] G. Beer, J. Vanderwerff, Structural properties of extended normed spaces, Set-Valued Var. Anal., 23(2015), no. 4, 613-630. 
[11] V. Berinde, Generalized contractions in quasimetric spaces, Semin. Fixed Point Theory ClujNapoca, 1993(1993), 3-9.

[12] V. Berinde, M. Choban, Generalized distances and their associate metrics. Impact on fixed point theory, Creat. Math. Inform., 22(2013), no. 1, 23-32.

[13] R.R. Coifman, M. de Guzman, Singular integrals and multipliers on homogeneous spaces, Rev. Unión Mat. Argent., 25(1970), 137-143.

[14] S. Czerwik, Contraction mappings in b-metric spaces, Acta Math. Inform. Univ. Ostrav., 1(1993), 5-11.

[15] S. Czerwik, Nonlinear set-valued contraction mappings in B-metric spaces, Atti Semin. Mat. Fis. Univ. Modena, 46(1998), no. 2, 263-276.

[16] S. Czerwik, K. Król, Cantor, Banach and Baire theorems in generalized metric spaces, in: Mathematical Analysis, Approximation Theory and Their Applications, (Th.M. Rassias, V. Gupta - Eds.) Cham, Springer, 2016, 139-144.

[17] S. Czerwik, K. Król, Completion of generalized metric spaces, Indian J. Math., 58(2016), no. $2,231-237$.

[18] S. Czerwik, K. Król, Generalized Minkowski functionals, in: Contributions in Mathematics and Engineering. In Honor of Constantin Carathéodory, (P.M. Pardalos, Th.M. Rassias - Eds.) Cham, Springer, 2016, 69-79.

[19] S. Czerwik, K. Król, Fixed point theorems in generalized metric spaces, Asian-Eur. J. Math., 10(2017), no. 2, 8 p.

[20] M.M. Deza, E. Deza, Encyclopedia of Distances, 3rd ed., Berlin, Springer, 2014.

[21] G. Dezső, Fixed point theorems in generalized metric spaces, Pure Math. Appl., 11(2000), no. $2,183-186$.

[22] J.B. Diaz, B. Margolis, A fixed point theorem of the alternative, for contractions on a generalized complete metric space, Bull. Amer. Math. Soc., 74(1968), 305-309.

[23] M. Edelstein, A remark on a theorem of A.F. Monna, Nederl. Akad. Wet., Proc., Ser. A, 67(1964), 88-89.

[24] R. Engelking, General Topology, Sigma Series in Pure Mathematics, vol. 6, Heldermann Verlag, Berlin, 1989, (translated from the Polish by the author).

[25] R. Fagin, R. Kumar, D. Sivakumar, Comparing top k lists, SIAM J. Discrete Math., 17(2003), no. $1,134-160$.

[26] R. Fagin, L. Stockmeyer, Relaxing the triangle inequality in pattern matching, International J. Computer Vision, 28(1998), no. 3, 134-160.

[27] A.H. Frink, Distance functions and the metrization problem, Bull. Amer. Math. Soc., 43(1937), 133-142.

[28] A. Granas, J. Dugundji, Fixed Point Theory, Springer, New York, NY, 2003.

[29] J. Heinonen, Lectures on Analysis on Metric Spaces, Springer, New York, 2001.

[30] C.F.K. Jung, On generalized complete metric spaces, Bull. Amer. Math. Soc., 75(1969), 113-116.

[31] M.A. Khamsi, Remarks on cone metric spaces and fixed point theorems of contractive mappings, Fixed Point Theory Appl., 2010(2010), 7 p.

[32] M.A. Khamsi, Generalized metric spaces: a survey, J. Fixed Point Theory Appl., 17(2015), no. $3,455-475$

[33] M.A. Khamsi, N. Hussain, KKM mappings in metric type spaces, Nonlinear Anal., 73(2010), no. 9, 3123-3129.

[34] W. Kirk, N. Shahzad, Fixed Point Theory in Distance Spaces, Cham, Springer, 2014.

[35] W.A.J. Luxemburg, On the convergence of successive approximations in the theory of ordinary differential equations, Canad. Math. Bull., 1(1958), 9-20.

[36] W.A.J. Luxemburg, On the convergence of successive approximations in the theory of ordinary differential equations. II, Nederl. Akad. Wet., Proc., Ser. A, 61(1958), 540-546.

[37] W.A.J. Luxemburg, On the convergence of successive approximations in the theory of ordinary differential equations. III, Nieuw Arch. Wiskd., III. Ser., 6(1958), 93-98.

[38] R.A. Mac'1as, C. Segovia, Lipschitz functions on spaces of homogeneous type, Adv. Math., 33(1979), 257-270. 
[39] R.A. Macías, C. Segovia, Singular integrals on generalized Lipschitz and Hardy spaces, Stud. Math., 65(1979), 55-75.

[40] B. Margolis, On some fixed points theorems in generalized complete metric spaces, Bull. Amer. Math. Soc., 74(1968), 275-282.

[41] A.F. Monna, Sur un théorème de M. Luxemburg concernant les points fixes d'une classe d'application d'un espace métrique dans lui-même, Nederl. Akad. Wet., Proc., Ser. A, 64(1961), 89-96.

[42] M. Paluszyński, K. Stempak, On quasi-metric and metric spaces, Proc. Amer. Math. Soc., 137(2009), no. 12, 4307-4312.

[43] A.I. Perov, On the Cauchy problem for a system of ordinary differential equations, (Russian), Priblizhen. Metody Reshen. Differ. Uravn. Vyp. 2, (1964), 115-134.

[44] A.I. Perov, Generalized principle of contraction mappings, (Russian), Vestn. Voronezh. Gos. Univ., Ser. Fiz. Mat., 2005(2005), no. 1, 196-207.

[45] A.I. Perov, A.V. Kibenko, On a certain general method for investigation of boundary value problems, (Russian), Izv. Akad. Nauk SSSR, Ser. Mat., 30(1966), 249-264.

[46] I.A. Rus, A. Petruşel, G. Petruşel, Fixed Point Theory, Cluj University Press, Cluj-Napoca, 2008.

[47] V. Schroeder, Quasi-metric and metric spaces, Conform. Geom. Dyn., 10(2006), 355-360.

[48] Q. Xia, The geodesic problem in quasimetric spaces, J. Geom. Anal., 19(2009), no. 2, 452-479.

Received: January 9, 2018; Accepted: March 10, 2018. 